\title{
Living-Donor Liver Transplantation and Hepatitis C
}

\author{
Nobuhisa Akamatsu ${ }^{1,2}$ and Yasuhiko Sugawara ${ }^{2}$ \\ ${ }^{1}$ Department of Hepato-Biliary-Pancreatic Surgery, Saitama Medical Center, Saitama Medical University, 1981 Tsujido-cho, Kamoda, \\ Kawagoe, Saitama 350-8550, Japan \\ ${ }^{2}$ Artificial Organ and Transplantation Division, Department of Surgery, Graduate School of Medicine, University of Tokyo, \\ 7-3-1 Hongo, Bunkyo-ku, Tokyo 113-8655, Japan \\ Correspondence should be addressed to Yasuhiko Sugawara; yasusugatky@yahoo.co.jp
}

Received 17 May 2012; Accepted 1 January 2013

Academic Editor: Andrea Lauterio

Copyright (C) 2013 N. Akamatsu and Y. Sugawara. This is an open access article distributed under the Creative Commons Attribution License, which permits unrestricted use, distribution, and reproduction in any medium, provided the original work is properly cited.

\begin{abstract}
Hepatitis-C-virus- (HCV-) related end-stage cirrhosis is the primary indication for liver transplantation in many countries. Unfortunately, however, HCV is not eliminated by transplantation and graft reinfection is universal, resulting in fibrosis, cirrhosis, and finally graft decompression. In areas with low deceased-donor organ availability like Japan, living-donor liver transplantation (LDLT) is similarly indicated for HCV cirrhosis as deceased-donor liver transplantation (DDLT) in Western countries and accepted as an established treatment for HCV-cirrhosis, and the results are equivalent to those of DDLT. To prevent graft failure due to recurrent hepatitis $\mathrm{C}$, antiviral treatment with pegylated-interferon and ribavirin is currently considered the most promising regimen with a sustained viral response rate of around $30 \%$ to $35 \%$, although the survival benefit of this regimen remains to be investigated. In contrast to DDLT, many Japanese LDLT centers have reported modified treatment regimens as best efforts to secure first graft, such as aggressive preemptive antiviral treatment, escalation of dosages, and elongation of treatment duration.
\end{abstract}

\section{Introduction}

Since the first successful application of living donor liver transplantation (LDLT) in 1990 [1] and subsequent successful LDLT for adult recipient in 1994 [2], the use of live donors for liver transplantation has been widely applied to adult recipients where the availability of deceased-donors is severely restricted, like in Japan [3], and also accepted as a solution to the cadaveric donor shortage in Western countries [4].

End-stage liver disease caused by chronic hepatitis $\mathrm{C}$ virus (HCV) infection is the leading cause of liver transplantation in developed countries [5, 6], including Japan [7]. Unfortunately, liver transplantation does not cure HCV-infected recipients, but re-infection of HCV universally occurs and disease progression is accelerated compared with that in the nontransplant population, resulting in poor outcomes for HCV-infected recipients [8].

The aim of this paper was to overview the current trends and controversies in LDLT for patients with HCV in relation to the perspectives from deceased-donor liver transplantation (DDLT).

\section{Natural History of Hepatitis C after Orthotopic Liver Transplantation}

Accumulating perspectives of disease recurrence in HCVinfected recipients have been obtained in DDLT within the last two decades. HCV reinfection occurs just after reperfusion followed by a rapid increase in $\mathrm{HCV}$ ribonucleic acid (RNA) levels within 4 postoperative months [9]. The histologic features of liver injury usually resemble those of nontransplant HCV hepatitis typically developing after 3 months, but the clinical presentation, severity, and outcome are extremely heterogeneous and more profound compared to those in immune competent patients [10]. Progression to cirrhosis usually takes 9 to 12 years after liver transplantation with a linear progression of histologic fibrosis $[10,11]$. A less common, but well-documented, form of 
recurrence is called fibrosing cholestatic hepatitis $(<10 \%)$, possibly mediated by a direct cytopathic mechanism under an extremely high viral load and immune-compromised condition. Graft failure occurs in 50\% of recipients within a few months after fibrosing cholestatic hepatitis develops [12]. Some HCV-reinfected recipients, however, show no apparent disease progression for at least the first decade and their graft injury remains mild or even absent despite a high vira burden.

Overall, cirrhosis develops in approximately $25 \%$ of liver transplant recipients (range $8 \%-44 \%$ ) after 5 to 10 years and this percentage is likely to increase with an increase in the follow-up period $[10,11]$. Once cirrhosis is complete, survival time is severely decreased and decompression is encountered with cumulative rates at 1 and 3 years of $40 \%$ and $60 \%$, respectively, which finally results in graft failure $[11,13]$.

The development of decompensated cirrhosis due to recurrent hepatitis $\mathrm{C}$ is now the most frequent cause of graft failure, patient death, and the need for retransplantation in HCV-infected recipients [11, 13-17]. As a result, survival is significantly decreased compared with other indications, an overall 10\% difference at 3 years [18]. In the most recent United Network for Organ Sharing/Organ Procurement and Transplantation Network (UNOS/OPTN) study from the United States, 3-year survival is $78 \%$ among 7459 HCVpositive recipients compared with $82 \%$ among $20734 \mathrm{HCV}$ negative recipients $(P<0.0001$; http://www.unos.org $)$ [19].

The poor outcome of HCV-positive recipients has resulted in the divergence in transplant outcomes between HCV-positive recipients and HCV-negative recipients. Improvements in organ preservation, surgical techniques, and postoperative care have dramatically improved the survival of HCV-negative recipients over the last two decades, whereas this has not been the case in HCV-positive recipients for whom outcome has remained unchanged or even worsened over time [19-22].

\section{Current Status of LDLT}

In areas with low deceased-donor organ availability like Japan, the indication of LDLT for HCV cirrhosis is similar to that of DDLT [7], whereas in Western countries, LDLT is conducted in an attempt to alleviate the shortage of donor organs and decrease the mortality among patients awaiting transplants, accounting for only $3 \%$ to $4 \%$ of all liver transplants [23].

According to the Japan Liver Transplantation Society [24], a total of 6097 LDLTs, comprising 98\% of all liver transplants, have been performed till the end of 2010 in Japan. Among those, 3796 were adult cases including 1200 (32\%) cases of HCV-related disease as a leading indication for adult LDLT. The 1, 3, 5, and 10 year survival rates of all adult LDLT and those of HCV-positive adults were $81 \%, 75 \%, 72 \%$, and $66 \%$, and $78 \%, 72 \%, 68 \%$, and $59 \%$, respectively, without difference.

In the United States, nearly 3000 LDLTs have been performed by the end of 2009, with decreased number of cases annually, comprising only $4.5 \%$ of all liver transplants $[23,25,26]$.

\section{LDLT as a Risk Factor for Recurrent Hepatitis C Studies Comparing Outcomes of LDLT and DDLT}

Based on the significant negative impact of recurrent hepatitis $\mathrm{C}$ on recipients' outcome, it is critical to identify the factors related to severe recurrent hepatitis $C[8,13]$. In the transplant setting, many factors contribute to disease progression compared with nontransplant patients [13], including, viralrelated factors [10, 27-36], donor age [17, 37-43], recipientrelated factors [32, 44-49], graft and surgical factors [40, 50-57], and immunosuppressive agents [58-75] (Table 1) however, many aspects remain unclear and require further investigation [8]. Among those, the possibility of increased severity of recurrent HCV in LDLT patients had been one of the hottest debates. The benefit of LDLT might be offset if the outcome of LDLT for HCV-positive recipients is worse than that of DDLT.

Early studies raised some negative concerns regarding the outcomes of LDLT in HCV patients, such as a poorer graft outcome and earlier and more aggressive HCV recurrence after LDLT compared with DDLT [144-146]. Several theories have been proposed to explain the differences in $\mathrm{HCV}$ recurrence between LDLT and DDLT recipients. One possible explanation is that the intense hepatocyte proliferation that occurs in partial liver grafts may lead to increased viral translation and replication [145, 147-149]. Genetic donorrecipient similarity is another proposed mechanism for more severe HCV recurrence $[150,151]$. Recent studies, however, comparing outcomes of LDLT and DDLT in HCV-infected patients have not only failed to identify LDLT as a risk factor for more intense viral recurrence with impaired outcome, but also revealed improved results in LDLT recipients [39, 8495], which do not support the aforementioned speculations. Alternatively, recent studies favored the theory that outcomes of LDLT for HCV cirrhosis could be better than those of DDLT due to the younger donor age and shorter ischemic time of LDLT grafts. The studies comparing outcomes between LDLT and DDLT in HCV-infected recipients are summarized in Table 2.

While several earlier studies demonstrated impaired patient/graft survival and severe histologic findings in LDLT [144-146], the majority of studies reported equal or even improved outcomes both in patient/graft survival and in fibrosis progression in LDLT $[39,84-95]$. Since the large UNOS database study [87] demonstrated comparable shortterm (24 months) survival between LDLT and DDLT, subsequent studies with considerable follow-up period have been published demonstrating comparable or even superior outcome in LDLT. Five-year patient survival ranged $71 \%$ to $84 \%$ in HCV-positive LDLT recipients among studies with sufficient follow-up period [39, 86, 94, 95]. Additionally, as Terrault et al. [92] reported, the learning curve for the LDLT procedure may have a considerable impact on the outcome of LDLT for HCV cirrhosis, which has been repeatedly pointed 
TABLE 1: Factors associated with the severity of recurrent hepatitis $\mathrm{C}$ after liver transplantation.

\begin{tabular}{|c|c|}
\hline Variables & Effect on recurrent hepatitis $\mathrm{C}$ \\
\hline \multicolumn{2}{|l|}{ Donor and graft factors } \\
\hline Age $[17,37-43]$ & More severe disease $(>40,>50,>65)$ \\
\hline Steatosis $[56,57,76-79]$ & Few studies \\
\hline Prolonged ischemic time $[54,55,80-83]$ & More severe disease \\
\hline $\mathrm{HCV}+$ graft $[6,22,40,50-53,76]$ & No influence \\
\hline Reduced size versus whole liver (LDLT versus DDLT) $[39,84-95]$ & No difference \\
\hline \multicolumn{2}{|l|}{ Pretransplant recipient factors } \\
\hline Genotype $1 \mathrm{~b}[8,32,33,35,40]$ & Controversial \\
\hline Pre-LT higher viral load $[21,28,96,97]$ & Unclear \\
\hline Age $[32,44,98]$ & Few studies \\
\hline Race $[45,46,99]$ & Few studies \\
\hline Sex $[20,47,48]$ & Few studies \\
\hline HIV coinfection $[100-107]$ & No influence \\
\hline IL-28B gene polymorphism $[49,108-111]$ & More severe disease in CT and TT genotype \\
\hline \multicolumn{2}{|l|}{ Posttransplant recipient factors } \\
\hline Post-LT higher viral load $[10,27-31]$ & More severe disease \\
\hline CMV infection $[22,29,32,112-116]$ & Unclear \\
\hline Diabetes mellitus (Metabolic syndrome) $[29,117-121]$ & More severe disease \\
\hline \multicolumn{2}{|l|}{ Immunosuppression } \\
\hline Steroid bolus/OKT3 $[6,21,22,58,59,122-124]$ & More severe disease \\
\hline Maintenance steroid $[34,60-62,122]$ & Severe disease when rapidly tapered \\
\hline Steroid free regimen $[63-68,125-127]$ & No influence \\
\hline Tacrolimus versus cyclosporine [69-75] & No difference \\
\hline Anti-IL-2 receptor antibodies $[63,126,128-131]$ & Controversial \\
\hline Azathioprine/mycophenolate mofetil [132-140] & Controversial \\
\hline mTOR inhibitors [141-143] & Few studies \\
\hline
\end{tabular}

CMV: cytomegalovirus; DDLT: deceased-donor liver transplantation; HCV: hepatitis C virus; HIV: human immunodeficiency virus; LDLT: living-donor liver transplantation; LT: liver transplantation; mTOR: mammalian target of rapamycin.

out by recent authors. Actually, none of reports after 2005 has found impaired outcome in LDLT.

These data should be interpreted with caution, however, because of the important clinical distinction between LDLT and DDLT. At the time of transplantation, DDLT recipients are far sicker than LDLT recipients as represented by a significantly higher MELD score, donor age is higher, and graft ischemic time is longer. Indeed, significantly poorer preoperative condition and older donor age in DDLT recipients were indicated in 7 and 6 studies, respectively, among 16 studies listed in Table 2. Additionally, cold ischemia time is significantly longer in DDLT than that in LDLT in all studies. All these factors, as presented in Table 1, are considered independent prognostic factors for severe $\mathrm{HCV}$ recurrence and impaired patient/graft outcome. Actually, Jain et al. [95], who recently reported that both patient/graft survival and histologic findings are better in LDLT, found in a subanalysis of the study that adjusting for MELD score $(<25)$ and donor age $(<50)$ resulted in similar outcomes.

Based on accumulating reports demonstrating comparable outcome of LDLT and DDLT for HCV cirrhosis, and refinement of surgical techniques and management in LDLT, hepatitis $\mathrm{C}$ recurrence by itself does not seem to explain the differences in patient/graft survival between LDLT and
DDLT, and even improved outcomes could be achieved in LDLT due to the better quality of the graft, younger donors, and less sick recipient condition at the time of transplantation. Furthermore, based on these benefits of LDLT, donor selection to improve outcome of LDLT for HCV positive recipients could be assumed. Selecting younger donors [17] or donors with favorable IL-28B genotype $[108,109]$ could be possible future issues; however, with the severe lack of live donors, it seems impractical in clinical setting at present. Anyway, LDLT could be strongly recommended for HCVpositive patients whenever it is available.

\section{Antiviral Treatment}

Antiviral treatments for recurrent hepatitis $\mathrm{C}$ after liver transplantation include eradication of the $\mathrm{HCV}$ virus before transplantation with the use of pretransplant antiviral treatment, eradication of HCV virus early after transplantation preemptively to prevent graft damage, and treatment for established recurrent hepatitis $\mathrm{C}$ in the acute, or more commonly, chronic phase. Regardless of the antiviral treatment timing, interferon (INF), especially pegylated-INF (PEGINF), in conjunction with ribavirin (RBV), is currently accepted as a standard key drug in achieving high sustained 


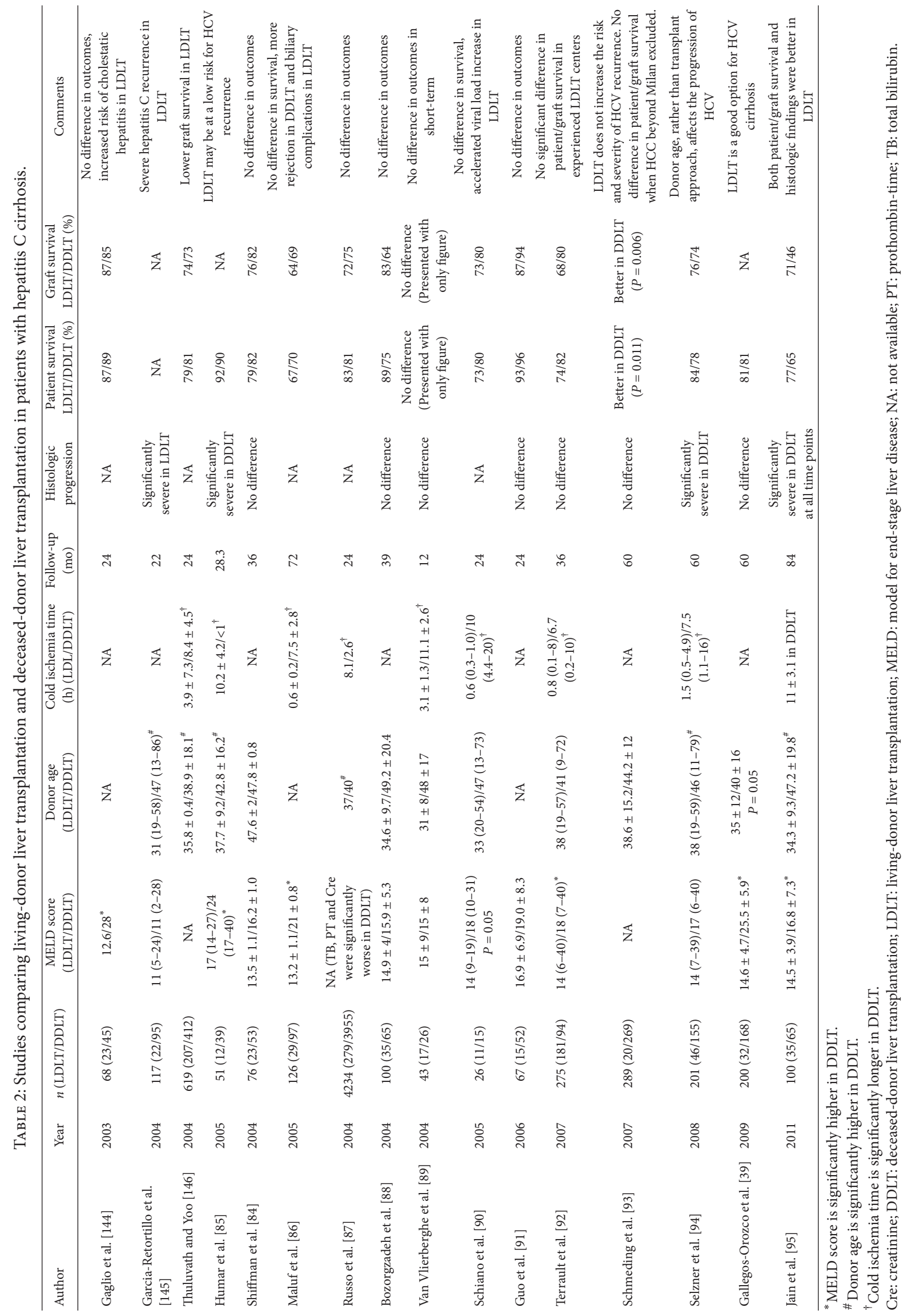


viral response (SVR) rate according to the perspectives obtained in nontransplant populations.

Former two strategies, however, have almost been abandoned in Western countries. Pretransplant treatment is severely limited by poor liver function, a high prevalence of nonresponders, severe cytopenia, and complications, including life-threatening infections [152], and to date, only six studies [153-158] have been published in this phase with differences in the treatment duration (6-14 months versus 2-3 months) and in regimens used (INF only, INF/RBV, or PEG-INF/RBV). Regardless of the approach used, the results are similar, resulting in the prevention of $\mathrm{HCV}$ re-infection in about $20 \%$ of treated patients with high discontinuation rate and high dose reduction rate [152]. Considering the less severe disease of LDLT recipients as discussed earlier, pretransplant antiviral treatment seems more preferable for LDLT recipients to improve outcome; however, no such trial has been published so far in LDLT setting. This issue also seems remain to be investigated in future studies as with the case in live donor selection issues.

Prophylactic or preemptive antiviral treatment generally means antiviral treatment with INF/PEG-INF and RBV started early posttransplant, without requiring evidence of recurrent hepatitis C. In published studies [159-164] of preemptive antiviral therapy, SVR rates are reported to range from $8 \%$ to $34 \%$ (5\% to $43 \%$ for genotype 1 and $14 \%$ to $100 \%$ for genotypes 2 or 3 ), with the rates of dose reduction and drug discontinuation are approximately $70 \%$ and $30 \%$, respectively, due to the existence of cytopenia, renal dysfunction, rejection, or extrahepatic complications, and high levels of immunosuppression in this time window. The most recently published prospective, multicenter, randomized study (PHOENIX study) by Bzowej et al. [165] was designed to compare the efficacy, tolerability, and safety of an escalating dose regimen of PEG-INF alpha 2a/RBV for 48 weeks for preemptive antiviral treatment versus no treatment, which showed only $22 \%$ SVR in the prophylaxis patients with the rate of marked HCV recurrence at 120 weeks (62\% in prophylaxis patients versus $65 \%$ in observation patients), and comparable fibrosis progression 120 weeks as well as similar patient/graft survival in both study arms. Dose reduction and discontinuation were required in $70 \%$ and $28 \%$, respectively. Based on these results, European and United States transplant societies do not support the routine use of preemptive antiviral therapy.

Consequently, initiating antiviral therapy with PEGINF/RBV after the confirmation of recurrent hepatitis $C$ in the graft by liver biopsies is the mainstay for the treatment of recurrent disease in Western countries [35, 166-190]. Most of the data come from uncontrolled studies with different designs regarding time to start treatment, regimen used, and follow-up, but treatment duration is generally 48 to 52 weeks. Therefore, the results were also very different, with SVR rates ranging $0 \%$ to $56 \%$ (median: $33 \%$ ), discontinuation rates ranging $4 \%$ to $58 \%$, and dose reduction rate ranging $28 \%$ to $100 \%$. In addition, the survival benefit of the treatment has not been confirmed in most studies so far, and it is compelling to conclude that there is currently no evidence to support the antiviral treatment for recurrent graft hepatitis $\mathrm{C}$ due to the lack of clinical benefit and frequent adverse effects, as concluded by the recent Cochrane meta-analysis [191]. On the other hand, recent retrospective cohort studies with a considerable follow-up duration found improved patient/graft survival in patients who obtained an SVR after antiviral treatment [35, 192-194]. Further randomized clinical trials with appropriate trial methodology and adequate follow-up duration are necessary to confirm an actual survival benefit of antiviral treatment.

\section{Reports from Japanese LDLT Centers}

Although retransplantation is the only potentially curative option for those with decompressed cirrhosis due to recurrent hepatitis $\mathrm{C}$, in contrast to Western countries where reDDLT is spared as a last resort $[195,196]$, it is extremely unlikely in Japan to perform retransplantation for patients with recurrent end-stage hepatitis $C$, if not absolutely impossible. These backgrounds might have led to various modified strategies for the treatment of recurrent disease as best efforts to secure first graft, such as aggressive preemptive antiviral treatment, escalation of dosages, and elongation of treatment duration.

We have reported preemptive INF/RBV treatment for HCV-positive LDLT recipients [161, 197-199]. Preemptive treatment was started just after recipient's condition had become stable (approximately one month after LDLT) with low-dose INF alpha $2 \mathrm{~b}$ and RBV ( $400 \mathrm{mg} /$ day) followed by escalation to PEG-INF ( $1.5 \mu \mathrm{g} / \mathrm{kg}$ per week) and RBV ( $800 \mathrm{mg} /$ day) depending on patient's tolerance. The treatment duration was not settled, and was continued for additional 12 months after the serum HCV-RNA became negative. The response was considered to be SVR provided negative serologic results for another 6 months after discontinuation of therapy. That is, nonstopping peg-INF/RBV approach was applied for non-responders. Among $122 \mathrm{HCV}$-positive LDLT recipients, 42 (34\%) achieved SVR and those with SVR showed significantly improved survival when compared to those without SVR (cumulative 5-year survival rate; 97\% versus 66\%) [199].

Kyoto group also reported modified PEG-INF/RBV treatment with individualized extension, while they started antiviral treatment for cases with biopsy-proven recurrent disease [200-202]. They started with PEG-INF $(1.5 \mu \mathrm{g} / \mathrm{kg}$ per week) and RBV (400-800 mg/day) for 12 months for all patients with recurrent hepatitis. Then, full dose treatment was continued for additional 8-22 months for those whose serum HCV-RNA became negative within 12 months, while patients who did not become negative for serum HCV RNA within 12 months continued to receive a low-dose PEGINF $(0.5-0.75 \mu \mathrm{g} / \mathrm{kg}$ per week) with or without reduced RBV $(200 \mathrm{mg} /$ day) as maintenance treatment. Among 80 patients with recurrent hepatitis C after LDLT, SVR was achieved in 31 (39\%), while remaining 49 (61\%) received maintenance therapy among those 26 (53\%) discontinued. In comparison to fibrosis progression, no difference was observed between SVR group and maintenance treatment group with improved or stable fibrosis in both groups, while those who withdrew 
from maintenance showed significantly deteriorated fibrosis [202].

Kyushu group performed antiviral treatment for 80 patients among 106 consecutive HCV-positive recipients, excluding 26 cases of early death, negative HCV RNA, and refusal for treatment [203]. Basically, they started with PEG-INF $(0.5 \mu \mathrm{g} / \mathrm{kg}$ per week) and RBV (200 mg/day), then escalated to PEG-INF ( $1.5 \mu \mathrm{g} / \mathrm{kg}$ per week) and RBV $(800 \mathrm{mg} /$ day), with the treatment duration of 48 weeks and over 72 weeks for those with early viral response and for those without it, respectively. They reported overall SVR rate of $35 \%$. They found both significantly severe fibrosis and impaired graft survival in those who did not show viral nor biochemical response.

Other Japanese centers [204-207] have also reported similar modified antiviral treatment with PEG-INF and RBV including dose escalation, treatment for all $\mathrm{HCV}$-positive cases, and extension of treatment. Additionally, simultaneous splenectomy during LDLT operation in an attempt to improve tolerance to antiviral treatment, SVR rate and further graft survival should be noticed [198, 208, 209].

\section{Conclusion}

Hepatitis $\mathrm{C}$ is here to stay and will remain the most common indication for liver transplantation. In the areas where cadaveric organs are extremely limited like in Japan, indication of LDLT is same as that of DDLT, and recent studies have proved that LDLT can be performed as safely and effectively as DDLT for HCV-infected patients in experienced centers. Further investigation for more effective and tolerable antiviral treatment is warranted to secure the first live donor graft to the possible extent.

\section{Abbreviations}

$\begin{array}{ll}\text { DDLT: } & \text { Deceased-donor liver transplantation } \\ \text { HCV: } & \text { Hepatitis C virus } \\ \text { HIV: } & \text { Human immunodeficiency virus } \\ \text { INF: } & \text { Interferon } \\ \text { LDLT: } & \text { Living-donor liver transplantation } \\ \text { MELD: } & \text { Model for end-stage liver disease } \\ \text { MMF: } & \text { Mycophenolate mofetil } \\ \text { mTOR: } & \text { Mammalian target of rapamycin } \\ \text { PEG-INF: } & \text { Pegylated-interferon } \\ \text { RBV: } & \text { Ribavirin } \\ \text { RNA: } & \text { Ribonucleic acid } \\ \text { SVR: } & \text { Sustained viral response } \\ \text { UNOS/OPTN: The United Network for Organ } \\ & \text { Sharing/Organ Procurement and } \\ & \text { Transplantation Network. }\end{array}$

\section{References}

[1] R. W. Strong, S. V. Lynch, T. H. Ong, H. Matsunami, Y. Koido, and G. A. Balderson, "Successful liver transplantation from a living donor to her son," New England Journal of Medicine, vol. 322, no. 21, pp. 1505-1507, 1990.
[2] Y. Hashikura, M. Makuuchi, S. Kawasaki et al., "Successful living-related partial liver transplantation to an adult patient," Lancet, vol. 343, no. 8907, pp. 1233-1234, 1994.

[3] Y. Sugawara and M. Makuuchi, "Advances in adult living donor liver transplantation: a review based on reports from the 10th anniversary of the adult-to-adult living donor liver transplantation meeting in Tokyo," Liver Transplantation, vol. 10, no. 6, pp. 715-720, 2004.

[4] R. M. Merion, "Current status and future of liver transplantation," Seminars in Liver Disease, vol. 30, no. 4, pp. 411-421, 2010.

[5] R. Adam, P. McMaster, J. G. O’Grady et al., "Evolution of liver transplantation in Europe: report of the European liver transplant registry," Liver Transplantation, vol. 9, no. 12, pp. 1231-1243, 2003.

[6] R. H. Wiesner, M. Sorrell, F. Villamil et al., "Report of the first international liver transplantation society expert panel consensus conference on liver transplantation and hepatitis C," Liver Transplantation, vol. 9, no. 11, pp. S1-S9, 2003.

[7] Y. Sugawara and M. Makuuchi, "Living donor liver transplantation to patients with hepatitis C virus cirrhosis," World Journal of Gastroenterology, vol. 12, no. 28, pp. 4461-4465, 2006.

[8] M. Berenguer, R. Charco, J. M. Pascasio et al., "Spanish society of liver transplantation (SETH) consensus recommendations on hepatitis C virus and liver transplantation," Liver International, vol. 32, no. 5, pp. 712-713, 2012.

[9] M. Garcia-Retortillo, X. Forns, A. Feliu et al., "Hepatitis C virus kinetics during and immediately after liver transplantation," Hepatology, vol. 35, no. 3, pp. 680-687, 2002.

[10] E. J. Gane, B. G. Portmann, N. V. Naoumov et al., "Long-term outcome of hepatitis C infection after liver transplantation," New England Journal of Medicine, vol. 334, no. 13, pp. 815-820, 1996.

[11] M. Berenguer, M. Prieto, J. M. Rayón et al., "Natural history of clinically compensated hepatitis $\mathrm{C}$ virus-related graft cirrhosis after liver transplantation," Hepatology, vol. 32, no. 4, part 1, pp. 852-858, 2000.

[12] T. K. Narang, W. Ahrens, and M. W. Russo, "Post-liver transplant cholestatic hepatitis $\mathrm{C}$ : a systematic review of clinical and pathological findings and application of consensus criteria," Liver Transplantation, vol. 16, no. 11, pp. 1228-1235, 2010.

[13] B. Roche and D. Samuel, "Risk factors for hepatitis C recurrence after liver transplantation," Journal of Viral Hepatitis, vol. 14, no. 1, pp. 89-96, 2007.

[14] L. M. Forman, J. D. Lewis, J. A. Berlin, H. I. Feldman, and M. R. Lucey, "The association between hepatitis $\mathrm{C}$ infection and survival after orthotopic liver transplantation," Gastroenterology, vol. 122, no. 4, pp. 889-896, 2002.

[15] M. Ghabril, R. Dickson, and R. Wiesner, "Improving outcomes of liver retransplantation: an analysis of trends and the impact of hepatitis C infection," American Journal of Transplantation, vol. 8, no. 2, pp. 404-411, 2008.

[16] M. Berenguer, "Natural history of recurrent hepatitis C," Liver Transplantation, vol. 8, no. 10, supplement 1, pp. S14-S18, 2002.

[17] M. Berenguer, M. Prieto, F. S. Juan et al., "Contribution of donor age to the recent decrease in patient survival among HCV-infected liver transplant recipients," Hepatology, vol. 36, no. 1, pp. 202-210, 2002.

[18] A. Rubin, V. Aguilera, and M. Berenguer, "Liver transplantation and hepatitis C," Clinics and Research in Hepatology and Gastroenterology, vol. 35, no. 12, pp. 805-812, 2011. 
[19] P. J. Thuluvath, K. L. Krok, D. L. Segev, and H. Y. Yoo, “Trends in post-liver transplant survival in patients with hepatitis C between 1991 and 2001 in the United States," Liver Transplantation, vol. 13, no. 5, pp. 719-724, 2007.

[20] L. S. Belli, A. K. Burroughs, P. Burra et al., "Liver transplantation for HCV cirrhosis: improved survival in recent years and increased severity of recurrent disease in female recipients: results of a long term retrospective study," Liver Transplantation, vol. 13, no. 5, pp. 733-740, 2007.

[21] M. Berenguer, L. Ferrell, J. Watson et al., "HCV-related fibrosis progression following liver transplantation: increase in recent years," Journal of Hepatology, vol. 32, no. 4, pp. 673-684, 2000.

[22] D. Samuel, X. Forns, M. Berenguer et al., "Report of the monothematic EASL conference on liver transplantation for viral hepatitis," Journal of Hepatology, vol. 45, no. 1, pp. 127-143, 2006

[23] K. M. Olthoff, M. M. Abecassis, J. C. Emond et al., "Outcomes of adult living donor liver transplantation: comparison of the adult-to-adult living donor liver transplantation cohort study and the national experience," Liver Transplantation, vol. 17, no. 7, pp. 789-797, 2011.

[24] The Japanese Liver Transplantation Society, "Liver transplantation in Japan. Registry by the Japanese liver transplantation society," Japanese Journal of Transplantation, vol. 46, no. 6, pp. 524-536, 2011.

[25] M. G. Ghany, D. B. Strader, D. L. Thomas, and L. B. Seeff, "Diagnosis, management, and treatment of hepatitis C: an update," Hepatology, vol. 49, no. 4, pp. 1335-1374, 2009.

[26] P. A. Vagefi, N. L. Ascher, C. E. Freise et al., "Use of living donor liver transplantation varies with the availability of deceased donor liver transplantation," Liver Transplantation, vol. 18, no. 2, pp. 160-165, 2012.

[27] E. J. Gane, N. V. Naoumov, K. P. Qian et al., "A longitudinal analysis of hepatitis $\mathrm{C}$ virus replication following liver transplantation," Gastroenterology, vol. 110, no. 1, pp. 167-177, 1996.

[28] R. Sreekumar, A. Gonzalez-Koch, Y. Maor-Kendler et al., "Early identification of recipients with progressive histologic recurrence of hepatitis C after liver transplantation," Hepatology, vol. 32, no. 5, pp. 1125-1130, 2000.

[29] I. A. Hanouneh, A. E. Feldstein, A. J. McCullough et al., "The significance of metabolic syndrome in the setting of recurrent hepatitis C after liver transplantation," Liver Transplantation, vol. 14, no. 9, pp. 1287-1293, 2008.

[30] G. V. Papatheodoridis, S. G. Barton, D. Andrew et al., "Longitudinal variation in hepatitis $\mathrm{C}$ virus $(\mathrm{HCV})$ viraemia and early course of HCV infection after liver transplantation for HCV cirrhosis: the role of different immunosuppressive regimens," Gut, vol. 45, no. 3, pp. 427-434, 1999.

[31] N. A. Shackel, J. Jamias, W. Rahman et al., "Early high peak hepatitis C viral load levels independently predict hepatitis Crelated liver failure post-liver transplantation," Liver Transplantation, vol. 15, no. 7, pp. 709-718, 2009.

[32] C. Feray, L. Caccamo, G. J. Alexander et al., "European collaborative study on factors influencing outcome after liver transplantation for hepatitis C. European concerted action on viral hepatitis (EUROHEP) group," Gastroenterology, vol. 117, no. 3, pp. 619-625, 1999.

[33] H. E. Vargas, T. Laskus, L. F. Wang et al., "The influence of hepatitis C virus genotypes on the outcome of liver transplantation," Liver Transplantation and Surgery, vol. 4, no. 1, pp. 22-27, 1998.
[34] M. Berenguer, J. Crippin, R. Gish et al., "A model to predict severe HCV-related disease following liver transplantation," Hepatology, vol. 38, no. 1, pp. 34-41, 2003.

[35] N. Selzner, E. L. Renner, M. Selzner et al., "Antiviral treatment of recurrent Hepatitis $\mathrm{C}$ after liver transplantation: predictors of response and long-term outcome," Transplantation, vol. 88, no. 10, pp. 1214-1221, 2009.

[36] C. Féray, M. Gigou, D. Samuel et al., "Influence of the genotypes of hepatitis $C$ virus on the severity of recurrent liver disease after liver transplantation," Gastroenterology, vol. 108, no. 4, pp. 1088-1096, 1995.

[37] D. G. Maluf, E. B. Edwards, R. T. Stravitz, and H. M. Kauftman, "Impact of the donor risk index on the outcome of hepatitis C virus-positive Liver transplant recipients," Liver Transplantation, vol. 15, no. 6, pp. 592-599, 2009.

[38] K. Rifai, M. Sebagh, V. Karam et al., "Donor age influences 10-year liver graft histology independently of hepatitis $C$ virus infection," Journal of Hepatology, vol. 41, no. 3, pp. 446-453, 2004.

[39] J. F. Gallegos-Orozco, A. Yosephy, B. Noble et al., "Natural history of post-liver transplantation hepatitis C: a review of factors that may influence its course," Liver Transplantation, vol. 15, no. 12, pp. 1872-1881, 2009.

[40] A. P. Khapra, K. Agarwal, M. I. Fiel et al., "Impact of donor age on survival and fibrosis progression in patients with hepatitis $\mathrm{C}$ undergoing liver transplantation using $\mathrm{HCV}+$ allografts," Liver Transplantation, vol. 12, no. 10, pp. 1496-1503, 2006.

[41] S. C. Rayhill, Y. M. Wu, D. A. Katz et al., "Older donor livers show early severe histological activity, fibrosis, and graft failure after liver transplantation for hepatitis C," Transplantation, vol. 84, no. 3, pp. 331-339, 2007.

[42] V. I. Machicao, H. Bonatti, M. Krishna et al., "Donor age affects fibrosis progression and graft survival after liver transplantation for hepatitis C," Transplantation, vol. 77, no. 1, pp. 84-92, 2004.

[43] A. W. Avolio, U. Cillo, M. Salizzoni et al., "Balancing donor and recipient risk factors in liver transplantation: the value of $\mathrm{D}$ MELD with particular reference to HCV recipients," American Journal of Transplantation, vol. 11, no. 12, pp. 2724-2736, 2011.

[44] M. Selzner, A. Kashfi, N. Selzner et al., "Recipient age affects long-term outcome and hepatitis $\mathrm{C}$ recurrence in old donor livers following transplantation," Liver Transplantation, vol. 15, no. 10, pp. 1288-1295, 2009.

[45] P. S. Pang, A. Kamal, and J. S. Glenn, "The effect of donor race on the survival of black Americans undergoing liver transplantation for chronic hepatitis C," Liver Transplantation, vol. 15, no. 9, pp. 1126-1132, 2009.

[46] V. Saxena, J. C. Lai, J. G. O. 'Leary et al., "Donor-recipient race mismatch in African-American ant patients with chronic hepatitis C," Liver Transplantation, vol. 18, no. 5, pp. 524-531, 2012.

[47] T. Walter, J. Dumortier, O. Guillaud, V. Hervieu, J. Y. Scoazec, and O. Boillot, "Factors influencing the progression of fibrosis in patients with recurrent hepatitis $\mathrm{C}$ after liver transplantation under antiviral therapy: a retrospective analysis of 939 liver biopsies in a single center," Liver Transplantation, vol. 13, no. 2, pp. 294-301, 2007.

[48] J. C. Lai, E. C. Verna, R. S. Brown et al., "Hepatitis C virusinfected women have a higher risk of advanced fibrosis and graft loss after liver transplantation than men," Hepatology, vol. 54, no. 2, pp. 418-424, 2011.

[49] M. R. Charlton, A. Thompson, B. J. Veldt et al., "Interleukin-28B polymorphisms are associated with histological recurrence and 
treatment response following liver transplantation in patients with hepatitis C virus infection," Hepatology, vol. 53, no. 1, pp. 317-324, 2011.

[50] P. G. Northup, C. K. Argo, D. T. Nguyen et al., "Liver allografts from hepatitis $\mathrm{C}$ positive donors can offer good outcomes in hepatitis $\mathrm{C}$ positive recipients: a us national transplant registry analysis," Transplant International, vol. 23, no. 10, pp. 1038-1044, 2010.

[51] J. I. Arenas, H. E. Vargas, and J. Rakela, "The use of hepatitis Cinfected grafts in liver transplantation," Liver Transplantation, vol. 9, no. 11, pp. S48-S51, 2003.

[52] R. Ballarin, A. Cucchetti, M. Spaggiari et al., "Long-term followup and outcome of liver transplantation from anti-hepatitis C virus-positive donors: a European multicentric case-control study," Transplantation, vol. 91, no. 11, pp. 1265-1272, 2011.

[53] A. T. Burr, Y. Li, J. F. Tseng et al., "Survival after liver transplantation using hepatitis $\mathrm{C}$ virus-positive donor allografts: casecontrolled analysis of the UNOS database," World Journal of Surgery, vol. 35, no. 7, pp. 1590-1595, 2011.

[54] K. D. S. Watt, E. R. Lyden, J. M. Gulizia, and T. M. McCashland, "Recurrent hepatitis C posttransplant: early preservation injury may predict poor outcome," Liver Transplantation, vol. 12, no. 1, pp. 134-139, 2006.

[55] P. W. Baron, D. Sindram, D. Higdon et al., "Prolonged rewarming time during allograft implantation predisposes to recurrent hepatitis $\mathrm{C}$ infection after liver transplantation," Liver Transplantation, vol. 6, no. 4, pp. 407-412, 2000.

[56] D. Brandman, A. Pingitore, J. C. Lai et al., "Hepatic steatosis at 1 year is an additional predictor of subsequent fibrosis severity in liver transplant recipients with recurrent hepatitis C virus," Liver Transplantation, vol. 17, no. 12, pp. 1380-1386, 2011.

[57] V. Subramanian, A. B. Seetharam, N. Vachharajani et al., "Donor graft steatosis influences immunity to hepatitis $C$ virus and allograft outcome after liver transplantation," Transplantation, vol. 92, no. 11, pp. 1259-1268, 2011.

[58] J. R. Lake, "The role of immunosuppression in recurrence of hepatitis C," Liver Transplantation, vol. 9, no. 11, pp. S63-S66, 2003.

[59] P. A. Sheiner, M. E. Schwartz, E. Mor et al., "Severe or multiple rejection episodes are associated with early recurrence of hepatitis C after orthotopic liver transplantation," Hepatology, vol. 21, no. 1, pp. 30-34, 1995.

[60] M. Berenguer, V. Aguilera, M. Prieto et al., "Significant improvement in the outcome of $\mathrm{HCV}$-infected transplant recipients by avoiding rapid steroid tapering and potent induction immunosuppression," Journal of Hepatology, vol. 44, no. 4, pp. 717-722, 2006.

[61] S. Brillanti, M. Vivarelli, N. de Ruvo et al., "Slowly tapering off steroids protects the graft against hepatitis $\mathrm{C}$ recurrence after liver transplantation," Liver Transplantation, vol. 8, no. 10, pp. 884-888, 2002.

[62] M. Vivarelli, P. Burra, G. L. Barba et al., "Influence of steroids on HCV recurrence after liver transplantation: a prospective study," Journal of Hepatology, vol. 47, no. 6, pp. 793-798, 2007.

[63] G. B. Klintmalm, G. L. Davis, L. Teperman et al., "A randomized, multicenter study comparing steroid-free immunosuppression and standard immunosuppression for liver transplant recipients with chronic hepatitis C," Liver Transplantation, vol. 17, no. 12, pp. 1394-1403, 2011.

[64] G. Sgourakis, A. Radtke, I. Fouzas et al., "Corticosteroid-free immunosuppression in liver transplantation: a meta-analysis and meta-regression of outcomes," Transplant International, vol. 22, no. 9, pp. 892-905, 2009.

[65] C. Margarit, I. Bilbao, L. Castells et al., "A prospective randomized trial comparing tacrolimus and steroids with tacrolimus monotherapy in liver transplantation: the impact on recurrence of hepatitis C," Transplant International, vol. 18, no. 12, pp. 1336-1345, 2005.

[66] T. Kato, J. J. Gaynor, H. Yoshida et al., "Randomized trial of steroid-free induction versus corticosteroid maintenance among orthotopic liver transplant recipients with hepatitis C virus: impact on hepatic fibrosis progression at one year," Transplantation, vol. 84, no. 7, pp. 829-835, 2007.

[67] L. Lladó, J. Fabregat, J. Castellote et al., "Impact of immunosuppression without steroids on rejection and hepatitis $C$ virus evolution after liver transplantation: results of a prospective randomized study," Liver Transplantation, vol. 14, no. 12, pp. 1752-1760, 2008.

[68] P. Manousou, D. Samonakis, E. Cholongitas et al., "Outcome of recurrent hepatitis $\mathrm{C}$ virus after liver transplantation in a randomized trial of tacrolimus monotherapy versus triple therapy," Liver Transplantation, vol. 15, no. 12, pp. 1783-1791, 2009.

[69] "Cyclosporine a-based immunosuppression reduces relapse rate after antiviral therapy in transplanted patients with hepatitis C virus infection: a large multicenter cohort study," Transplantation, vol. 92, no. 3, pp. 334-340, 2011.

[70] P. Martin, R. W. Busuttil, R. M. Goldstein et al., "Impact of tacrolimus versus cyclosporine in hepatitis $\mathrm{C}$ virus-infected liver transplant recipients on recurrent hepatitis: a prospective, randomized trial," Liver Transplantation, vol. 10, no. 10, pp. 1258-1262, 2004.

[71] J. G. O'Grady, P. Hardy, A. K. Burroughs et al., "Randomized controlled trial of tacrolimus versus microemulsified cyclosporin (TMC) in liver transplantation: poststudy surveillance to 3 years," American Journal of Transplantation, vol. 7, no. 1, pp. 137-141, 2007.

[72] G. Levy, G. L. Grazi, F. Sanjuan et al., "12-month followup analysis of a multicenter, randomized, prospective trial in de novo liver transplantation recipients (LIS2T) comparing cyclosporine microemulsion (C2 monitoring) and tacrolimus," Liver Transplantation, vol. 12, no. 10, pp. 1464-1472, 2006.

[73] M. Berenguer, V. Aguilera, F. San Juan et al., "Effect of calcineurin inhibitors in the outcome of liver transplantation in hepatitis C virus-positive recipients," Transplantation, vol. 90, no. 11, pp. 1204-1209, 2010.

[74] M. Berenguer, A. Royuela, and J. Zamora, "Immunosuppression with calcineurin inhibitors with respect to the outcome of HCV recurrence after liver transplantation: results of a metaanalysis," Liver Transplantation, vol. 13, no. 1, pp. 21-29, 2007.

[75] W. D. Irish, S. Arcona, D. Bowers, and J. F. Trotter, "Cyclosporine versus tacrolimus treated liver transplant recipients with chronic hepatitis C: outcomes analysis of the UNOS/OPTN database," American Journal of Transplantation, vol. 11, no. 8, pp. 1676-1685, 2011.

[76] M. Berenguer, "Risk of extended criteria donors in hepatitis C virus-positive recipients," Liver Transplantation, vol. 14, supplement 2, pp. S45-S50, 2008.

[77] A. Nocito, A. M. El-Badry, and P. A. Clavien, "When is steatosis too much for transplantation?" Journal of Hepatology, vol. 45, no. 4, pp. 494-499, 2006.

[78] S. M. Strasberg, T. K. Howard, E. P. Molmenti, and M. Hertl, "Selecting the donor liver: risk factors for poor function after 
orthotopic liver transplantation," Hepatology, vol. 20, no. 4, part 1, pp. 829-838, 1994.

[79] R. J. Ploeg, A. M. D’Alessandro, S. J. Knechtle et al., "Risk factors for primary dysfunction after liver transplantation-a multivariate analysis," Transplantation, vol. 55, no. 4, pp. 807-813, 1993.

[80] S. Feng, N. P. Goodrich, J. L. Bragg-Gresham et al., "Characteristics associated with liver graft failure: the concept of a donor risk index," American Journal of Transplantation, vol. 6, no. 4, pp. 783-790, 2006.

[81] J. Briceño, R. Ciria, M. Pleguezuelo et al., "Contribution of marginal donors to liver transplantation for hepatitis $\mathrm{C}$ virus infection," Transplantation Proceedings, vol. 39, no. 7, pp. 2297-2299, 2007.

[82] A. M. Cameron, R. M. Ghobrial, H. Yersiz et al., "Optimal utilization of donor grafts with extended criteria: a single-center experience in over 1000 liver transplants," Annals of Surgery, vol. 243, no. 6, pp. 748-753, 2006.

[83] R. Hernandez-Alejandro, K. P. Croome, D. Quan et al., "Increased risk of severe recurrence of hepatitis $\mathrm{C}$ virus in liver transplant recipients of donation after cardiac death allografts," Transplantation, vol. 92, no. 6, pp. 686-689, 2011.

[84] M. L. Shiffman, R. T. Stravitz, M. J. Contos et al., "Histologic recurrence of chronic hepatitis $\mathrm{C}$ virus in patients after living donor and deceased donor liver transplantation," Liver Transplantation, vol. 10, no. 10, pp. 1248-1255, 2004.

[85] A. Humar, K. Horn, A. Kalis, B. Glessing, W. D. Payne, and J. Lake, "Living donor and split-liver transplants in hepatitis $\mathrm{C}$ recipients: does liver regeneration increase the risk for recurrence?" American Journal of Transplantation, vol. 5, no. 2, pp. 399-405, 2005.

[86] D. G. Maluf, R. T. Stravitz, A. H. Cotterell et al., "Adult living donor versus deceased donor liver transplantation: a 6-year single center experience," American Journal of Transplantation, vol. 5, no. 1, pp. 149-156, 2005.

[87] M. W. Russo, J. Galanko, K. Beavers, M. W. Fried, and R. Shrestha, "Patient and graft surivival in hepatitis $\mathrm{C}$ recipients after adult living donor liver transplantation in the United States," Liver Transplantation, vol. 10, no. 3, pp. 340-346, 2004.

[88] A. Bozorgzadeh, A. Jain, C. Ryan et al., "Impact of hepatitis C viral infection in primary cadaveric liver allograft versus primary living-donor allograft in 100 consecutive liver transplant recipients receiving tacrolimus," Transplantation, vol. 77, no. 712, pp. 1066-1070, 2004.

[89] H. van Vlierberghe, R. Troisi, I. Colle, S. Ricciardi, M. Praet, and B. de Hemptinne, "Hepatitis C infection-related liver disease: patterns of recurrence and outcome in cadaveric and livingdonor liver transplantation in adults," Transplantation, vol. 77, no. 2, pp. 210-214, 2004.

[90] T. D. Schiano, J. A. Gutierrez, J. L. Walewski et al., "Accelerated hepatitis $\mathrm{C}$ virus kinetics but similar survival rates in recipients of liver grafts from living versus deceased donors," Hepatology, vol. 42, no. 6, pp. 1420-1428, 2005.

[91] L. Guo, M. Orrego, H. Rodriguez-Luna et al., "Living donor liver transplantation for hepatitis C-related cirrhosis: no difference in histological recurrence when compared to deceased donor liver transplantation recipients," Liver Transplantation, vol. 12, no. 4, pp. 560-565, 2006.

[92] N. A. Terrault, M. L. Shiffman, A. S. F. Lok et al., "Outcomes in hepatitis $\mathrm{C}$ virus-infected recipients of living donor vs. deceased donor liver transplantation," Liver Transplantation, vol. 13, no. 1, pp. 122-129, 2007.
[93] M. Schmeding, U. P. Neumann, G. Puhl, M. Bahra, R. Neuhaus, and P. Neuhaus, "Hepatitis $\mathrm{C}$ recurrence and fibrosis progression are not increased after living donor liver transplantation: a single-center study of 289 patients," Liver Transplantation, vol. 13, no. 5, pp. 687-692, 2007.

[94] N. Selzner, N. Girgrah, L. Lilly et al., "The difference in the fibrosis progression of recurrent hepatitis $\mathrm{C}$ after live donor liver transplantation versus deceased donor liver transplantation is attributable to the difference in donor age," Liver Transplantation, vol. 14, no. 12, pp. 1778-1786, 2008.

[95] A. Jain, A. Singhal, R. Kashyap et al., "Comparative analysis of hepatitis $\mathrm{C}$ recurrence and fibrosis progression between deceased-donor and living-donor liver transplantation: 8-year longitudinal follow-up," Transplantation, vol. 92, no. 4, pp. 453-460, 2011.

[96] M. Charlton, E. Seaberg, R. Wiesner et al., "Predictors of patient and graft survival following liver transplantation for hepatitis C," Hepatology, vol. 28, no. 3, pp. 823-830, 1998.

[97] G. W. McCaughan and A. Zekry, "Mechanisms of HCV reinfection and allograft damage after liver transplantation," Journal of Hepatology, vol. 40, no. 3, pp. 368-374, 2004.

[98] R. J. Firpi, M. F. Abdelmalek, C. Soldevila-Pico et al., "One-year protocol liver biopsy can stratify fibrosis progression in liver transplant recipients with recurrent hepatitis C infection," Liver Transplantation, vol. 10, no. 10, pp. 1240-1247, 2004.

[99] M. Moeller, A. Zalawadia, A. Alrayes, G. Divine, K. Brown, and D. Moonka, "The impact of donor race on recurrent hepatitis C after liver transplantation,” Transplantation Proceedings, vol. 42, no. 10, pp. 4175-4177, 2010.

[100] Y. Sugawara, S. Tamura, and N. Kokudo, "Liver transplantation in HCV/HIV positive patients," World Journal of Gastrointestinal Surgery, vol. 3, no. 2, pp. 21-28, 2011.

[101] J. C. Duclos-Vallee, C. Feray, M. Sebagh et al., "Survival and recurrence of hepatitis $\mathrm{C}$ after liver transplantation in patients coinfected with human immunodeficiency virus and hepatitis C virus," Hepatology, vol. 47, no. 2, pp. 407-417, 2008.

[102] J. C. Duclos-Vallee, B. Falissard, and D. Samuel, "Liver transplant outcomes in HIV-infected patients: a systematic review and meta-analysis with a synthetic cohort," AIDS, vol. 25, no. 13, pp. 1675-1676, 2011.

[103] A. Moreno, C. Cervera, J. Fortun et al., "Epidemiology and outcome of infections in human immunodeficiency virus/hepatitis C virus-coinfected liver transplant recipients: a FIPSE/GESIDA prospective cohort study," Liver Transplantation, vol. 18, no. 1, pp. 70-81, 2012.

[104] M. E. de Vera, I. Dvorchik, K. Tom et al., "Survival of liver transplant patients coinfected with HIV and HCV is adversely impacted by recurrent hepatitis C," American Journal of Transplantation, vol. 6, no. 12, pp. 2983-2993, 2006.

[105] J. Fung, B. Eghtesad, K. Patel-Tom, M. DeVera, H. Chapman, and M. Ragni, "Liver transplantation in patients with HIV infection," Liver Transplantation, vol. 10, no. 10, supplement 2, pp. S39-S53, 2004.

[106] K. Wojcik, M. Vogel, E. Voigt et al., "Antiviral therapy for hepatitis $\mathrm{C}$ virus recurrence after liver transplantation in HIVinfected patients: outcome in the Bonn cohort," AIDS, vol. 21, no. 10, pp. 1363-1365, 2007.

[107] N. M. Kemmer and K. E. Sherman, "Liver transplantation trends in the HIV population," Digestive Diseases and Sciences, vol. 56, no. 11, pp. 3393-3398, 2011.

[108] T. Fukuhara, A. Taketomi, T. Motomura et al., "Variants in IL28B in liver recipients and donors correlate with response to 
peg-interferon and ribavirin therapy for recurrent hepatitis C," Gastroenterology, vol. 139, no. 5, article e3, pp. 1577-1585, 2010.

[109] D. Eurich, S. Boas-Knoop, M. Ruehl et al., "Relationship between the interleukin-28b gene polymorphism and the histological severity of hepatitis $C$ virus-induced graft inflammation and the response to antiviral therapy after liver transplantation," Liver Transplantation, vol. 17, no. 3, pp. 289-298, 2011.

[110] C. M. Lange, D. Moradpour, A. Doehring et al., "Impact of donor and recipient IL28B rs12979860 genotypes on hepatitis C virus liver graft reinfection," Journal of Hepatology, vol. 55, no. 2, pp. 322-327, 2011.

[111] M. Coto-Llerena, G. Crespo, P. Gonzalez et al., "Determination of IL28B polymorphisms in liver biopsies obtained after liver transplantation," Journal of Hepatology, vol. 56, no. 2, pp. 355-358, 2012.

[112] H. R. Rosen, S. Chou, C. L. Corless et al., "Cytomegalovirus viremia: risk factor for allograft cirrhosis after liver transplantation for hepatitis C," Transplantation, vol. 64, no. 5, pp. 721-726, 1997.

[113] A. Humara, D. Kumar, J. Raboud et al., "Interactions between cytomegalovirus, human herpesvirus-6, and the recurrence of hepatitis C after liver transplantation," American Journal of Transplantation, vol. 2, no. 5, pp. 461-466, 2002.

[114] R. Teixeira, S. Pastacaldi, S. Davies et al., "The influence of cytomegalovirus viraemia on the outcome of recurrent hepatitis C after liver transplantation," Transplantation, vol. 70, no. 10, pp. 1454-1458, 2000.

[115] G. Nebbia, F. M. Mattes, E. Cholongitas et al., "Exploring the bidirectional interactions between human cytomegalovirus and hepatitis C virus replication after liver transplantation," Liver Transplantation, vol. 13, no. 1, pp. 130-135, 2007.

[116] A. Humar, K. Washburn, R. Freeman et al., "An assessment of interactions between hepatitis $\mathrm{C}$ virus and herpesvirus reactivation in liver transplant recipients using molecular surveillance," Liver Transplantation, vol. 13, no. 10, pp. 1422-1427, 2007.

[117] S. Baid, A. B. Cosimi, M. Lin Farrell et al., "Posttransplant diabetes mellitus in liver transplant recipients: risk factors, temporal, relationship with hepatitis $\mathrm{C}$ virus allograft hepatitis, and impact on mortality," Transplantation, vol. 72, no. 6, pp. 1066-1072, 2001.

[118] M. R. Foxton, A. Quaglia, R. Muiesan et al., "The impact of diabetes mellitus on fibrosis progression in patients transplanted for hepatitis C," American Journal of Transplantation, vol. 6, no. 8, pp. 1922-1929, 2006.

[119] A. A. AlDosary, A. S. Ramji, T. G. Elliott et al., "Post-liver transplantation diabetes mellitus: an association with hepatitis C," Liver Transplantation, vol. 8, no. 4, pp. 356-361, 2002.

[120] E. J. Gane, "Diabetes mellitus following liver transplantation in patients with hepatitis C virus: risks and consequences," American Journal of Transplantation, vol. 12, no. 3, pp. 531-538, 2012.

[121] B. J. Veldt, J. J. Poterucha, K. D. S. Watt et al., "Insulin resistance, serum adipokines and risk of fibrosis progression in patients transplanted for hepatitis C," American Journal of Transplantation, vol. 9, no. 6, pp. 1406-1413, 2009.

[122] D. N. Samonakis, C. K. Triantos, U. Thalheimer et al., "Immunosuppresion and donor age with respect to severity of HCV recurrence after liver transplantation," Liver Transplantation, vol. 11, no. 4, pp. 386-395, 2005.

[123] M. Charlton and E. Seaberg, "Impact of immunosuppression and acute rejection on recurrence of hepatitis C: results of the national institute of diabetes and digestive and kidney diseases liver transplantation database," Liver Transplantation and Surgery, vol. 5, no. 4, supplement 1, pp. S107-S114, 1999.

[124] U. P. Neumann, T. Berg, M. Bahra et al., "Long-term outcome of liver transplants for chronic hepatitis C: a 10-year follow-up," Transplantation, vol. 77, no. 2, pp. 226-231, 2004.

[125] J. D. Eason, S. Nair, A. J. Cohen, J. L. Blazek, and G. E. Loss, "Steroid-free liver transplantation using rabbit antithymocyte globulin and early tacrolimus monotherapy," Transplantation, vol. 75, no. 8, pp. 1396-1399, 2003.

[126] F. Filipponi, F. Callea, M. Salizzoni et al., "Double-blind comparison of hepatitis $\mathrm{C}$ histological recurrence rate in $\mathrm{HCV}+$ liver transplant recipients given basiliximab+steroids or basiliximab+placebo, in addition to cyclosporine and azathioprine," Transplantation, vol. 78, no. 10, pp. 1488-1495, 2004.

[127] D. L. Segev, S. M. Sozio, E. J. Shin et al., "Steroid avoidance in liver transplantation: meta-analysis and meta-regression of randomized trials," Liver Transplantation, vol. 14, no. 4, pp. 512-525, 2008.

[128] Y. Calmus, J. R. Scheele, I. Gonzalez-Pinto et al., "Immunoprophylaxis with basiliximab, a chimeric anti-interleukin-2 receptor monoclonal antibody, in combination with azathioprinecontaining triple therapy in liver transplant recipients," Liver Transplantation, vol. 8, no. 2, pp. 123-131, 2002.

[129] G. B. G. Klintmalm, W. K. Washburn, S. M. Rudich et al., "Corticosteroid-free immunosuppression with daclizumab in $\mathrm{HCV}+$ liver transplant recipients: 1-year interim results of the HCV-3 study," Liver Transplantation, vol. 13, no. 11, pp. 1521-1531, 2007.

[130] P. Neuhaus, P. A. Clavien, D. Kittur et al., "Improved treatment response with basiliximab immunoprophylaxis after liver transplantation: results from a double-blind randomized placebocontrolled trial," Liver Transplantation, vol. 8, no. 2, pp. 132-142, 2002.

[131] D. R. Nelson, C. Soldevila-Pico, A. Reed et al., "Antiinterleukin-2 receptor therapy in combination with mycophenolate mofetil is associated with more severe hepatitis $\mathrm{C}$ recurrence after liver transplantation," Liver Transplantation, vol. 7, no. 12, pp. 1064-1070, 2001.

[132] A. Jain, R. Kashyap, A. J. Demetris, B. Eghstesad, R. Pokharna, and J. J. Fung, "A prospective randomized trial of mycophenolate mofetil in liver transplant recipients with hepatitis C," Liver Transplantation, vol. 8, no. 1, pp. 40-46, 2002.

[133] R. H. Wiesner, J. S. Shorr, B. J. Steffen, A. H. Chu, R. D. Gordon, and J. R. Lake, "Mycophenolate mofetil combination therapy improves long-term outcomes after liver transplantation in patients with and without hepatitis C," Liver Transplantation, vol. 11, no. 7, pp. 750-759, 2005.

[134] F. Sánchez-Bueno, M. L. Ortiz, J. Bermejo et al., "Prognostic factors for hepatitis $\mathrm{C}$ recurrence in patients undergoing orthotopic liver transplantation," Transplant Immunology, vol. 17, no. 1, pp. 47-50, 2006.

[135] T. M. Manzia, R. Angelico, L. Toti et al., "Long-term, maintenance MMF monotherapy improves the fibrosis progression in liver transplant recipients with recurrent hepatitis C," Transplant International, vol. 24, no. 5, pp. 461-468, 2011.

[136] A. Kornberg, B. Küpper, J. Wilberg et al., "Conversion to mycophenolate mofetil for modulating recurrent hepatitis $\mathrm{C}$ in liver transplant recipients," Transplant Infectious Disease, vol. 9, no. 4, pp. 295-301, 2007.

[137] A. Kornberg, B. Küpper, A. Tannapfel, M. Hommann, and J. Scheele, "Impact of mycophenolate mofetil versus azathioprine 
on early recurrence of hepatitis C after liver transplantation," International Immunopharmacology, vol. 5, no. 1, pp. 107-115, 2005.

[138] M. Bahra, U. I. F. P. Neumann, D. Jacob et al., "MMF and calcineurin taper in recurrent hepatitis C after liver transplantation: impact on histological course," American Journal of Transplantation, vol. 5, no. 2, pp. 406-411, 2005.

[139] A. Zekry, M. Gleeson, S. Guney, and G. W. McCaughan, "A prospective cross-over study comparing the effect of mycophenolate versus azathioprine on allograft function and viral load in liver transplant recipients with recurrent chronic HCV infection," Liver Transplantation, vol. 10, no. 1, pp. 52-57, 2004.

[140] G. Germani, M. Pleguezuelo, F. Villamil et al., "Azathioprine in liver transplantation: a reevaluation of its use and a comparison with mycophenolate mofetil," American Journal of Transplantation, vol. 9, no. 8, pp. 1725-1731, 2009.

[141] T. Kawahara, S. Asthana, and N. M. Kneteman, "m-TOR inhibitors: what role in liver transplantation?" Journal of Hepatology, vol. 55, no. 6, pp. 1441-1451, 2011.

[142] S. Asthana, C. Toso, G. Meeberg et al., "The impact of sirolimus on hepatitis $\mathrm{C}$ recurrence after liver transplantation," Canadian Journal of Gastroenterology, vol. 25, no. 1, pp. 28-34, 2011.

[143] S. J. F. Harper, W. Gelson, I. G. Harper, G. J. M. Alexander, and P. Gibbs, "Switching to sirolimus-based immune suppression after liver transplantation is safe and effective: a single-center experience," Transplantation, vol. 91, no. 1, pp. 128-132, 2011.

[144] P. J. Gaglio, S. Malireddy, B. S. Levitt et al., "Increased risk of cholestatic hepatitis $\mathrm{C}$ in recipients of grafts from living versus cadaveric liver donors," Liver Transplantation, vol. 9, no. 10, pp. 1028-1035, 2003.

[145] M. Garcia-Retortillo, X. Forns, J. M. Llovet et al., "Hepatitis $\mathrm{C}$ recurrence is more severe after living donor compared to cadaveric liver transplantation," Hepatology, vol. 40, no. 3, pp. 699-707, 2004.

[146] P. J. Thuluvath and H. Y. Yoo, "Graft and patient survival after adult live donor liver transplantation compared to a matched cohort who received a deceased donor transplantation," Liver Transplantation, vol. 10, no. 10, pp. 1263-1268, 2004.

[147] N. Fausto and J. S. Campbell, "The role of hepatocytes and oval cells in liver regeneration and repopulation," Mechanisms of Development, vol. 120, no. 1, pp. 117-130, 2003.

[148] M. A. Zimmerman and J. F. Trotter, "Living donor liver transplantation in patients with hepatitis C," Liver Transplantation, vol. 9, no. 11, pp. S52-S57, 2003.

[149] K. M. Olthoff, "Hepatic regeneration in living donor liver transplantation," Liver Transplantation, vol. 9, no. 10, supplement 2, pp. S35-S41, 2003.

[150] G. T. Everson and J. Trotter, "Role of adult living donor liver transplantation in patients with hepatitis C," Liver Transplantation, vol. 9, no. 10, supplement 2, pp. S64-S68, 2003.

[151] R. Manez, R. Mateo, J. Tabasco, S. Kusne, T. E. Starzl, and R. J. Duquesnoy, "The influence of HLA donor-recipient compatibility on the recurrence of HBV and HCV hepatitis after liver transplantation," Transplantation, vol. 59, no. 4, pp. 640-642, 1995.

[152] B. Roche and D. Samuel, "Hepatitis C virus treatment preand post-liver transplantation," Liver International, vol. 32, supplement 1, pp. 120-128, 2012.

[153] J. A. Carrión, E. Martínez-Bauer, G. Crespo et al., "Antiviral therapy increases the risk of bacterial infections in HCVinfected cirrhotic patients awaiting liver transplantation: a retrospective study," Journal of Hepatology, vol. 50, no. 4, pp. 719-728, 2009.

[154] X. Forns, M. García-Retortillo, T. Serrano et al., "Antiviral therapy of patients with decompensated cirrhosis to prevent recurrence of hepatitis C after liver transplantation," Journal of Hepatology, vol. 39, no. 3, pp. 389-396, 2003.

[155] J. S. Crippin, T. McCashland, N. Terrault, P. Sheiner, and M. R. Charlton, "A pilot study of the tolerability and efficacy of antiviral therapy in hepatitis $\mathrm{C}$ virus-infected patients awaiting liver transplantation," Liver Transplantation, vol. 8, no. 4, pp. 350-355, 2002.

[156] G. T. Everson, J. Trotter, L. Forman et al., "Treatment of advanced hepatitis $\mathrm{C}$ with a low accelerating dosage regimen of antiviral therapy," Hepatology, vol. 42, no. 2, pp. 255-262, 2005.

[157] R. M. Thomas, J. J. Brems, G. Guzman-Hartman, S. Yong, P. Cavaliere, and D. H. van Thiel, "Infection with chronic hepatitis $\mathrm{C}$ virus and liver transplantation: a role for interferon therapy before transplantation," Liver Transplantation, vol. 9, no. 9, pp. 905-915, 2003.

[158] G. T. Everson, N. A. Terrault, A. S. Lok et al., "A randomized controlled trial of pretransplant antiviral therapy to prevent recurrence of hepatitis C after liver transplantation," Hepatology.

[159] A. K. Shergill, M. Khalili, S. Straley et al., "Applicability, tolerability and efficacy of preemptive antiviral therapy in hepatitis C-infected patients undergoing liver transplantation," American Journal of Transplantation, vol. 5, no. 1, pp. 118-124, 2005.

[160] V. Mazzaferro, A. Tagger, M. Schiavo et al., "Prevention of recurrent hepatitis $\mathrm{C}$ after liver transplantation with early interferon and ribavirin treatment," Transplantation Proceedings, vol. 33, no. 1-2, pp. 1355-1357, 2001.

[161] S. Tamura, Y. Sugawara, N. Yamashiki, J. Kaneko, N. Kokudo, and M. Makuuchi, "Pre-emptive antiviral therapy in living donor liver transplantation for hepatitis C: observation based on a single-center experience," Transplant International, vol. 23, no. 6, pp. 580-588, 2010.

[162] A. Kuo, V. Tan, B. Lan et al., "Long-term histological effects of preemptive antiviral therapy in liver transplant recipients with hepatitis C virus infection," Liver Transplantation, vol. 14, no. 10, pp. 1491-1497, 2008.

[163] N. Chalasani, C. Manzarbeitia, P. Ferenci et al., "Peginterferon alfa-2a for hepatitis $\mathrm{C}$ after liver transplantation: two randomized, controlled trials," Hepatology, vol. 41, no. 2, pp. 289-298, 2005.

[164] N. Singh, T. Gayowski, C. F. Wannstedt et al., "Interferon- $\alpha$ for prophylaxis of recurrent viral hepatitis $\mathrm{C}$ in liver transplant recipients: a prospective, randomized, controlled trial," Transplantation, vol. 65, no. 1, pp. 82-86, 1998.

[165] N. Bzowej, D. R. Nelson, N. A. Terrault et al., "PHOENIX: a randomized controlled trial of peginterferon alfa-2a plus ribavirin as a prophylactic treatment after liver transplantation for hepatitis C virus," Liver Transplantation, vol. 17, no. 5, pp. 528-538, 2011.

[166] B. Roche, M. Sebagh, M. L. Canfora et al., "Hepatitis C virus therapy in liver transplant recipients: response predictors, effect on fibrosis progression, and importance of the initial stage of fibrosis," Liver Transplantation, vol. 14, no. 12, pp. 1766-1777, 2008.

[167] M. Berenguer, V. Aguilera, M. Prieto et al., "Worse recent efficacy of antiviral therapy in liver transplant recipients with 
recurrent hepatitis C: impact of donor age and baseline cirrhosis," Liver Transplantation, vol. 15, no. 7, pp. 738-746, 2009.

[168] H. Rodriguez-Luna, A. Khatib, P. Sharma et al., "Treatment of recurrent hepatitis $C$ infection after liver transplantation with combination of pegylated interferon $\alpha 2 \mathrm{~b}$ and ribavirin: an open-label series," Transplantation, vol. 77, no. 2, pp. 190-194, 2004.

[169] G. W. Neff, M. Montalbano, C. B. O’Brien et al., "Treatment of established recurrent hepatitis $\mathrm{C}$ in liver-transplant recipients with pegylated interferon-alfa- $2 \mathrm{~b}$ and ribavirin therapy," Transplantation, vol. 78, no. 9, pp. 1303-1307, 2004.

[170] A. S. Ross, A. K. Bhan, M. Pascual, M. Thiim, A. B. Cosimi, and R. T. Chung, "Pegylated interferon $\alpha$-2b plus ribavirin in the treatment of post-liver transplant recurrent hepatitis C," Clinical Transplantation, vol. 18, no. 2, pp. 166-173, 2004.

[171] M. Babatin, L. Schindel, and K. W. Burak, "Pegylated-interferon alpha $2 \mathrm{~b}$ and ribavirin for recurrent hepatities $\mathrm{C}$ after liver liver transplantation: from a Canadian experience to recommendations for therapy," Canadian Journal of Gastroenterology, vol. 19, no. 6, pp. 359-365, 2005.

[172] L. Castells, V. Vargas, H. Allende et al., "Combined treatment with pegylated interferon $(\alpha-2 b)$ and ribavirin in the acute phase of hepatitis $C$ virus recurrence after liver transplantation," Journal of Hepatology, vol. 43, no. 1, pp. 53-59, 2005.

[173] P. Toniutto, C. Fabris, E. Fumo et al., "Pegylated versus standard interferon- $\alpha$ in antiviral regimens for post-transplant recurrent hepatitis C: comparison of tolerability and efficacy," Journal of Gastroenterology and Hepatology, vol. 20, no. 4, pp. 577-582, 2005.

[174] M. Berenguer, A. Palau, A. Fernandez et al., "Efficacy, predictors of response, and potential risks associated with antiviral therapy in liver transplant recipients with recurrent hepatitis C," Liver Transplantation, vol. 12, no. 7, pp. 1067-1076, 2006.

[175] M. Biselli, P. Andreone, A. Gramenzi et al., "Pegylated interferon plus ribavirin for recurrent Hepatitis $\mathrm{C}$ infection after liver transplantation in naive and non-responder patients on a stable immunosuppressive regimen," Digestive and Liver Disease, vol. 38 , no. 1, pp. 27-32, 2006.

[176] I. Fernández, J. C. Meneu, F. Colina et al., "Clinical and histological efficacy of pegylated interferon and ribavirin therapy of recurrent hepatitis C after liver transplantation," Liver Transplantation, vol. 12, no. 12, pp. 1805-1812, 2006.

[177] S. Mukherjee and E. Lyden, "Impact of pegylated interferon $\alpha-2 \mathrm{~B}$ and ribavirin on hepatic fibrosis in liver transplant patients with recurrent hepatitis C: an open-label series," Liver International, vol. 26, no. 5, pp. 529-535, 2006.

[178] U. Neumann, G. Puhl, M. Bahra et al., "Treatment of patients with recurrent hepatitis $\mathrm{C}$ after liver transplantation with peginterferon alfa-2B plus ribavirin," Transplantation, vol. 82, no. 1, pp. 43-47, 2006.

[179] E. Oton, R. Barcena, J. M. Moreno-Planas et al., "Hepatitis $\mathrm{C}$ recurrence after liver transplantation: viral and histologic response to full-dose peg-interferon and ribavirin," American Journal of Transplantation, vol. 6, no. 10, pp. 2348-2355, 2006.

[180] M. Angelico, A. Petrolati, R. Lionetti et al., "A randomized study on Peg-interferon alfa-2a with or without ribavirin in liver transplant recipients with recurrent hepatitis C", Journal of Hepatology, vol. 46, no. 6, pp. 1009-1017, 2007.

[181] J. A. Carrión, M. Navasa, M. García-Retortillo et al., "Efficacy of antiviral therapy on hepatitis $\mathrm{C}$ recurrence after liver transplantation: a randomized controlled study," Gastroenterology, vol. 132, no. 5, pp. 1746-1756, 2007.
[182] F. P. Picciotto, G. Tritto, A. G. Lanza et al., "Sustained virological response to antiviral therapy reduces mortality in HCV reinfection after liver transplantation," Journal of Hepatology, vol. 46, no. 3, pp. 459-465, 2007.

[183] P. Sharma, J. A. Marrero, R. J. Fontana et al., "Sustained virologic response to therapy of recurrent hepatitis $\mathrm{C}$ after liver transplantation is related to early virologic response and dose adherence," Liver Transplantation, vol. 13, no. 8, pp. 1100-1108, 2007.

[184] T. Zimmermann, W. O. Böcher, S. Biesterfeld et al., "Efficacy of an escalating dose regimen of pegylated interferon $\alpha-2 \mathrm{a}$ plus ribavirin in the early phase of HCV reinfection after liver transplantation," Transplant International, vol. 20, no. 7, pp. 583-590, 2007.

[185] I. A. Hanouneh, C. Miller, F. N. Aucejo, R. Lopez, M. K. Quinn, and N. N. Zein, "Recurrent hepatitis C after liver transplantation: on-treatment prediction of response to peginterferon/ribavirin therapy," Liver Transplantation, vol. 14, no. 1, pp. 53-58, 2008.

[186] F. Lodato, S. Berardi, A. Gramenzi et al., "Clinical trial: peginterferon alfa-2b and ribavirin for the treatment of genotype-1 hepatitis C recurrence after liver transplantation," Alimentary Pharmacology and Therapeutics, vol. 28, no. 4, pp. 450-457, 2008.

[187] S. Dinges, I. Morard, M. Heim et al., "Pegylated interferonalpha2a/ribavirin treatment of recurrent hepatitis $\mathrm{C}$ after liver transplantation," Transplant Infectious Disease, vol. 11, no. 1, pp. 33-39, 2009.

[188] A. Jain, R. Sharma, C. Ryan et al., "Response to antiviral therapy in liver transplant recipients with recurrent hepatitis $\mathrm{C}$ viral infection: a single center experience," Clinical Transplantation, vol. 24, no. 1, pp. 104-111, 2010.

[189] S. C. Schmidt, M. Bahra, S. Bayraktar et al., "Antiviral treatment of patients with recurrent hepatitis $\mathrm{c}$ after liver transplantation with pegylated interferon," Digestive Diseases and Sciences, vol. 55 , no. 7, pp. 2063-2069, 2010.

[190] W. Al-Hamoudi, H. Mohamed, F. Abaalkhail et al., "Treatment of genotype 4 hepatitis $C$ recurring after liver transplantation using a combination of pegylated interferon alfa- $2 \mathrm{a}$ and ribavirin," Digestive Diseases and Sciences, vol. 56, no. 6, pp. 1848-1852, 2011.

[191] K. S. Gurusamy, E. Tsochatzis, B. R. Davidson, and A. K. Burroughs, "Antiviral prophylactic intervention for chronic hepatitis C virus in patients undergoing liver transplantation," Cochrane Database of Systematic Reviews, no. 12, Article ID CD006573, 2010.

[192] B. J. Veldt, J. J. Poterucha, K. D. S. Watt et al., "Impact of pegylated interferon and ribavirin treatment on graft survival in liver transplant patients with recurrent hepatitis $\mathrm{C}$ infection," American Journal of Transplantation, vol. 8, no. 11, pp. 2426-2433, 2008.

[193] M. Berenguer, A. Palau, V. Aguilera, J. M. Rayón, F. S. Juan, and M. Prieto, "Clinical benefits of antiviral therapy in patients with recurrent hepatitis $\mathrm{C}$ following liver transplantation," American Journal of Transplantation, vol. 8, no. 3, pp. 679-687, 2008.

[194] R. J. Firpi, V. Clark, C. Soldevila-Pico et al., "The natural history of hepatitis $\mathrm{C}$ cirrhosis after liver transplantation," Liver Transplantation, vol. 15, no. 9, pp. 1063-1071, 2009.

[195] T. McCashland, K. Watt, E. Lyden et al., "Retransplantation for hepatitis C: results of a U.S. multicenter retransplant study," Liver Transplantation, vol. 13, no. 9, pp. 1246-1253, 2007. 
[196] J. Martí, R. Charco, J. Ferrer et al., "Optimization of liver grafts in liver retransplantation: a European single-center experience," Surgery, vol. 144, no. 5, pp. 762-769, 2008.

[197] Y. Sugawara, M. Makuuchi, Y. Matsui et al., "Preemptive therapy for hepatitis $\mathrm{C}$ virus after living-donor liver transplantation," Transplantation, vol. 78, no. 9, pp. 1308-1311, 2004.

[198] Y. Kishi, Y. Sugawara, N. Akamatsu et al., "Splenectomy and preemptive interferon therapy for hepatitis C patients after living-donor liver transplantation," Clinical Transplantation, vol. 19, no. 6, pp. 769-772, 2005.

[199] S. Tamura, Y. Sugawara, N. Yamashiki, J. Kaneko, N. Kokudo, and M. Makuuchi, "Preemptive antiviral treatment for hepatitis C virus after living donor liver transplantation," Transplantation Proceedings, vol. 44, no. 3, pp. 971-973, 2012.

[200] Y. Ueda, Y. Takada, H. Haga et al., "Limited benefit of biochemical response to combination therapy for patients with recurrent hepatitis C after living-donor liver transplantation," Transplantation, vol. 85, no. 6, pp. 855-862, 2008.

[201] Y. Ueda, Y. Takada, H. Marusawa, H. Egawa, S. Uemoto, and T. Chiba, "Individualized extension of pegylated interferon plus ribavirin therapy for recurrent hepatitis $\mathrm{C}$ genotype $1 \mathrm{~b}$ after living-donor liver transplantation," Transplantation, vol. 90, no. 6, pp. 661-665, 2010.

[202] Y. Ueda, H. Marusawa, T. Kaido et al., "Effect of maintenance therapy with low-dose peginterferon for recurrent hepatitis C after living donor liver transplantation," Journal of Viral Hepatitis, vol. 19, no. 1, pp. 32-38, 2012.

[203] T. Ikegami, A. Taketomi, Y. Soejima et al., “The benefits of interferon treatment in patients without sustained viral response after living donor liver transplantation for hepatitis C," Transplantation Proceedings, vol. 41, no. 10, pp. 4246-4252, 2009.

[204] S. Eguchi, M. Takatsuki, A. Soyama et al., "Intentional conversion from tacrolimus to cyclosporine for HCV-positive patients on preemptive interferon therapy after living donor liver transplantation," Annals of Transplantation, vol. 12, no. 4, pp. 11-15, 2007.

[205] T. Kawaoka, N. Hiraga, S. Takahashi et al., "Prolongation of interferon therapy for recurrent hepatitis $\mathrm{C}$ after living donor liver transplantation: analysis of predictive factors of sustained virological response, including amino acid sequence of the core and NS5A regions of hepatitis C virus," Scandinavian Journal of Gastroenterology, vol. 45, no. 12, pp. 1488-1496, 2010.

[206] Y. Masuda, Y. Nakazawa, K. Matsuda et al., "Clinicopathological features of hepatitis $\mathrm{C}$ virus disease after living donor liver transplantation: relationship with in situ hybridisation data," Pathology, vol. 43, no. 2, pp. 156-160, 2011.

[207] S. Marubashi, K. Dono, H. Nagano et al., "Steroid-free living donor liver transplantation in adults: impact on hepatitis C recurrence," Clinical Transplantation, vol. 23, no. 6, pp. 904-913, 2009.

[208] L. B. Jeng, C. C. Lee, H. C. Chiang et al., "Indication for splenectomy in the Era of living-donor liver transplantation," Transplantation Proceedings, vol. 40, no. 8, pp. 2531-2533, 2008.

[209] T. Yoshizumi, A. Taketomi, Y. Soejima et al., "The beneficial role of simultaneous splenectomy in living donor liver transplantation in patients with small-for-size graft," Transplant International, vol. 21, no. 9, pp. 833-842, 2008. 


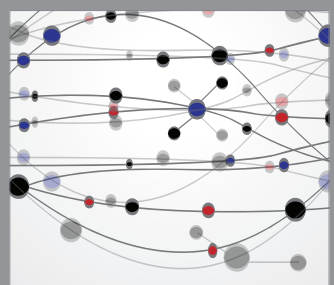

The Scientific World Journal
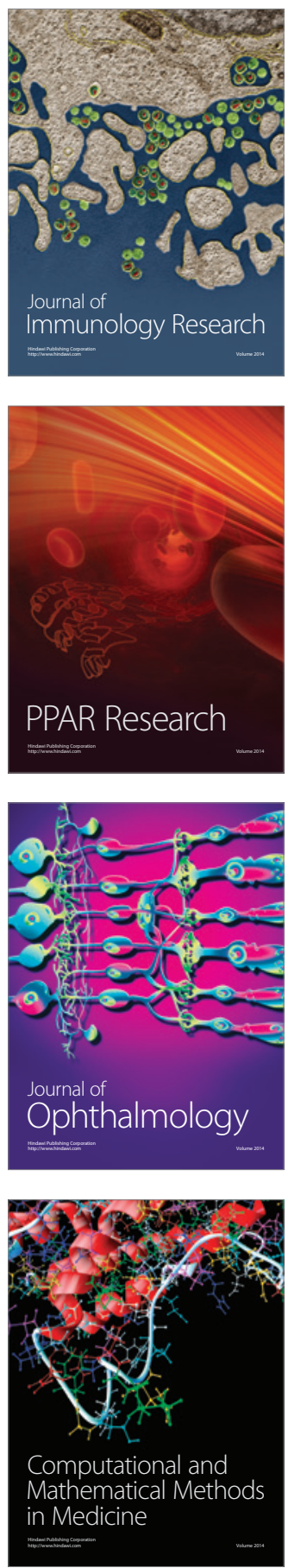

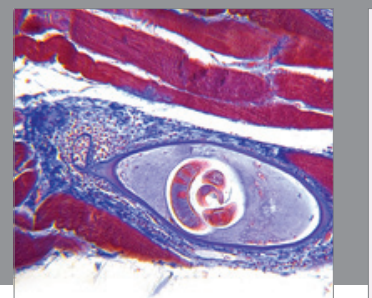

Gastroenterology

Research and Practice
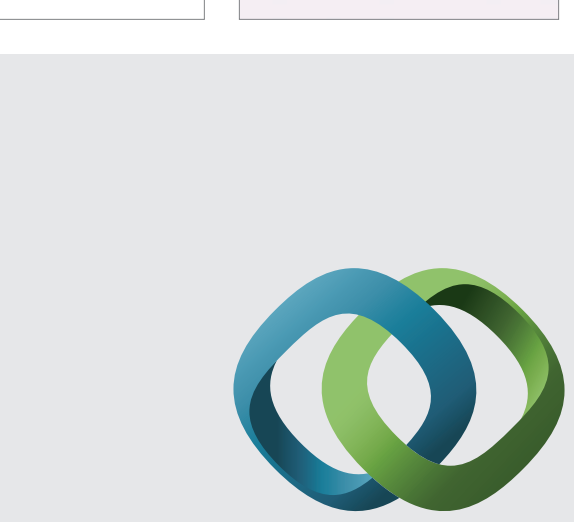

\section{Hindawi}

Submit your manuscripts at

http://www.hindawi.com
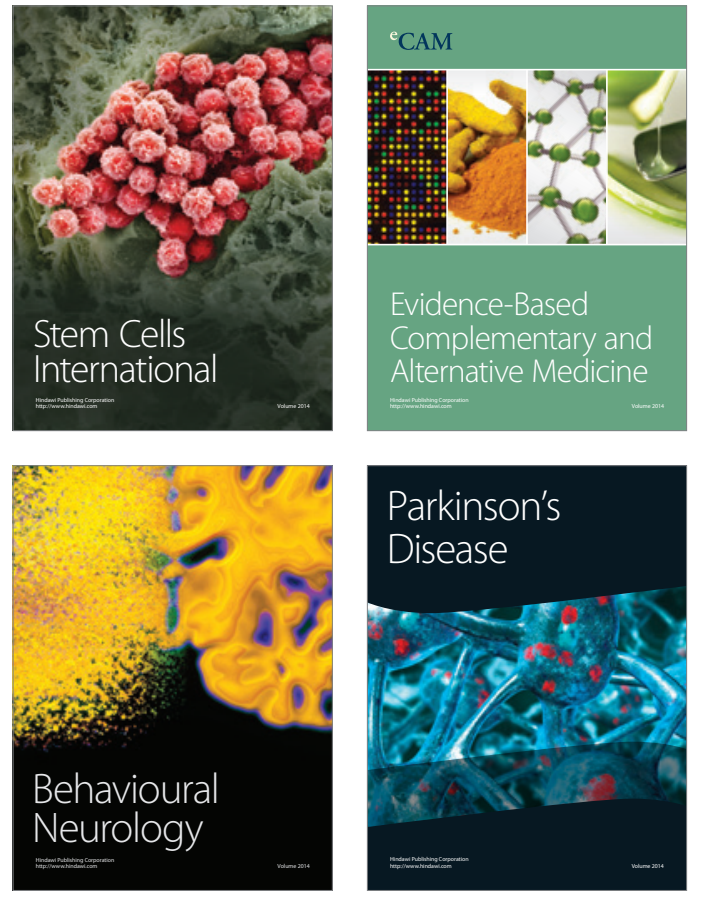
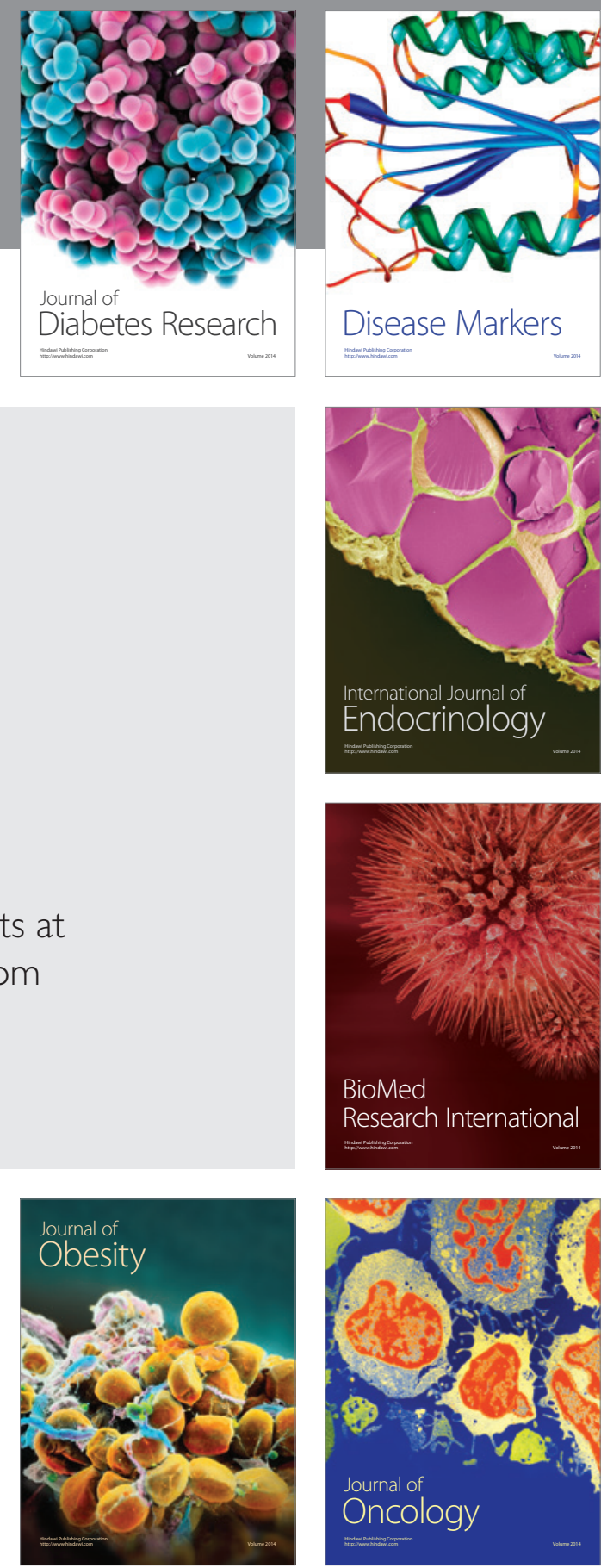

Disease Markers
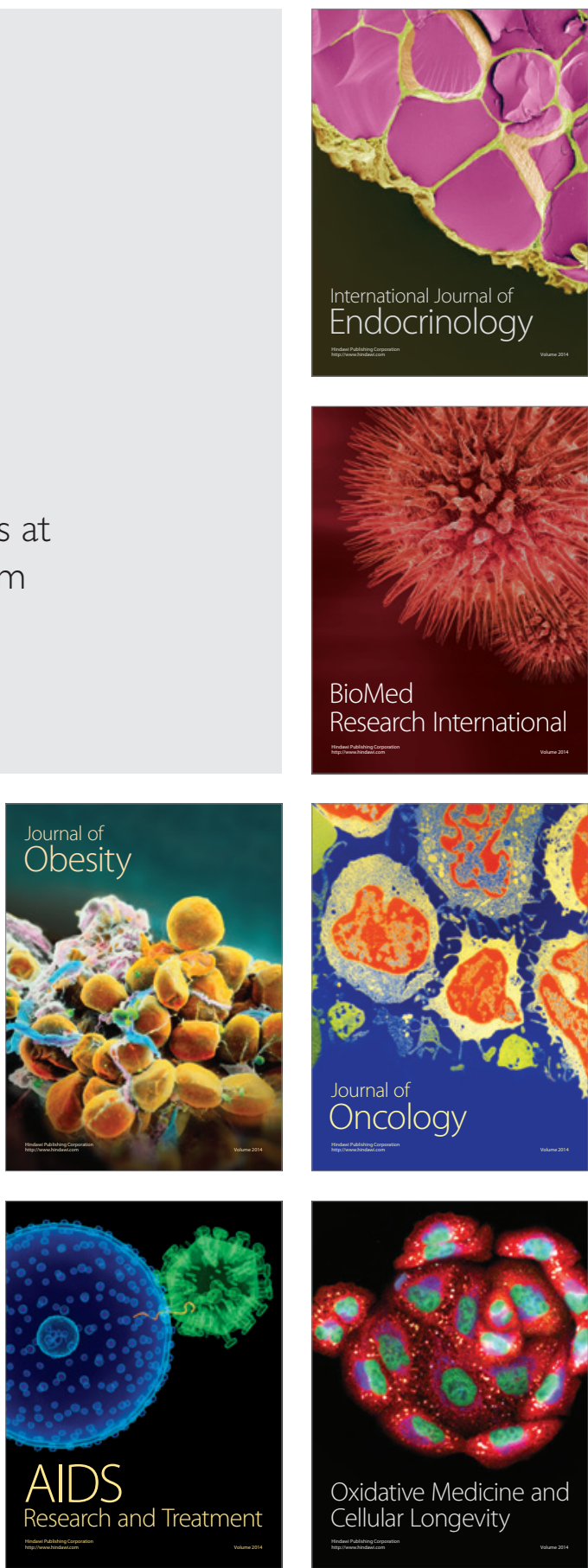